\title{
EXPANDING STATELESSNESS SCHOLARSHIP: THE VALUE OF INTERDISCIPLINARY RESEARCH AND EDUCATION
}

\author{
LINDSEY N KINGSTON*
}

My first introduction to the issue of statelessness was in northern Thailand, where stateless 'hill tribes' faced a gauntlet of human rights violations because they lacked the protections afforded to Thai nationals. ${ }^{1}$ Back in 2005, statelessness had failed to garner significant attention from the international community including non-governmental organisations ('NGOs') known for speaking out against such human suffering. ${ }^{2}$ The master's thesis and doctoral dissertation that followed this experience had very little 'statelessness research' to build from, although existing scholarship on citizenship, migration and social movements helped guide my way. Today, more than 13 years later, increased attention to this issue has spurred the growth of academic programs and resources aimed squarely at this topic. The Statelessness Programme at Tilburg University (the Netherlands) and the Peter McMullin Centre on Statelessness at Melbourne Law School (Australia), for instance, offer academic focal points for research and education on this issue. So do issue-specific NGOs such as the European Network on Statelessness and the Institute on Statelessness and Inclusion (based in the United Kingdom and the Netherlands, respectively). With this, the inaugural issue of the Statelessness and Citizenship Review, we are offered another resource for expanding statelessness scholarship and better understanding this oft-ignored issue. These developments are exciting, but they also place us at a pivotal time for determining the direction of research and teaching on statelessness; it is here, at this juncture, when we can (and should) make thoughtful, deliberate decisions about the best path forward. With this goal in mind, I offer my own reflections as an interdisciplinary scholar and educator who remains deeply committed to stateless individuals and to the protection of their fundamental human rights.

I have had the opportunity to teach the issue of statelessness at undergraduate and graduate levels, and in both cases my students are at first shocked that so many people around the globe lack any sort of legal nationality - and then are amazed that such a seemingly technical, legalistic issue can have so many real-life consequences. My undergraduate students are drawn from a wide variety of

* Lindsey N Kingston is an Associate Professor of International Human Rights at Webster University in Saint Louis, Missouri, where she directs the university's Institute for Human Rights and Humanitarian Studies. Kingston is a Fulbright Scholar whose work appears in a variety of edited volumes and peer-reviewed journals, including Journal of Human Rights, Forced Migration Review, Journal of Human Rights Practice, and International Journal of Refugee Law. Kingston's monograph Fully Human: Personhood, Citizenship, and Rights is available from Oxford University Press.

1 See, eg, Conny Rijken et al, The Nexus between Statelessness and Human Trafficking in Thailand (Wolf Legal 2015).

2 Lindsey N Kingston, “"A Forgotten Human Rights Crisis": Statelessness and Issue (Non) Emergence' (2013) 14(2) Human Rights Review 73. 
disciplines; some are majors in the international human rights program that I direct at Webster University, but far more are taking an introductory human rights course to fulfil a general education requirement toward graduation. As we start the semester and explore the Universal Declaration of Human Rights ('UDHR'), they are initially interested in rights and issues they are familiar with and perhaps already outraged by: discrimination against LGBTQI and racial minority groups, human trafficking, child soldiering, denied access to healthcare and education.

As we connect the fundamental rights outlined in the $U D H R$ with our own lives - including what we see as necessities to live a life of dignity - rarely does anyone think to include citizenship, passports or other forms of identity cards on our list of basic needs. Recently, as the plight of the Rohingya has emerged within the mainstream media following widespread violence and forced displacement beginning in August 2017, ${ }^{3}$ the word 'stateless' might come up as an afterthought in their discussions of refugees and genocide. (Although most students, at first glance, believe that this statelessness means that the Rohingya do not have their own country — not that they are denied citizenship by Myanmar's discriminatory nationality law). ${ }^{4}$ Yet rarely do I have an undergraduate student start the semester with statelessness on their intellectual 'radar', much less hoping to prioritise the issue in their study of international human rights.

At the graduate level, I have taught students earning master's degrees in international relations at my home institution (in Saint Louis, United States of America, as well as at our campus in Leiden, the Netherlands), and also at the Università degli Studi di Milano in Italy. While these students come into the classroom with far more sophisticated ideas about international law, rights and citizenship, they are similarly surprised by the pervasiveness of statelessness and its negative consequences. This is true not only for Americans - who live in a country where jus soli nationality laws make statelessness less common, although certainly far from impossible — but also for students who have lived and worked in places where lack of nationality is far more widespread. By the time we reached the end of my spring 2018 'Statelessness and the "Right to Have Rights"' course in Milan, one student - who in fact came from a country in Eastern Europe facing persistent problems with statelessness - was exasperated by the issue's lack of visibility and attention. 'This whole term, I've been telling people about statelessness', she said. 'And nobody knows about it. They know about refugees, sure, but not about statelessness. They don't know what it means, they don't know how it's everywhere. They just don't get it'. As is often the case, students came into the class without prior knowledge of statelessness; but once they learned about its scope and consequences, they became passionate defenders of nationality rights.

Given these experiences, it is tempting to call for a field of 'statelessness studies' that focuses specifically on this long-ignored issue. Yet as a human rights educator and an interdisciplinary social scientist, I urge caution with this idea or at least ask us to consider carefully our next steps. Human rights, including the fundamental right to a nationality, are interconnected and interdependent; 'unless (nearly) all internationally recognized human rights are respected, a life of full

3 Council on Foreign Relations, 'The Rohingya Crisis' (5 December 2018) $<$ https://www.cfr.org/backgrounder/rohingya-crisis $>$.

4 The 1982 Burma Citizenship Law does not recognise the Rohingya as one of the country's national races, effectively denying them the possibility of acquiring legal nationality. 
dignity is unlikely to be a realistic possibility'. ${ }^{5}$ To consider statelessness in isolation reduces it to a legal gap, a bureaucratic oversight, a glitch that can be remedied with a state ID card or passport. If statelessness was really only about a lack of legal status - brought about by exclusion from a nationality law or unregistered babies, for instance - its impacts would not be so devastating and its solutions would be infinitely easier to realise.

The truth is that statelessness is both a cause and a symptom of marginalisation; that is, 'most stateless populations lack legal nationality because they are part of a marginalized group that faces systematic discrimination and oppression from the start. Their circumstances are greatly harmed by their statelessness, yet the acquisition of legal nationality alone will not ensure their access to human rights'. 6 This complexity is why I argue that a narrow emphasis on citizenship acquisition as a 'solution' for statelessness is misguided, and that legal status is only 'one step in a long journey toward full rights protection'. ${ }^{7}$ My longstanding interest in the issue of statelessness - and hence, my sympathy for the desire to create a field of 'statelessness studies' - is tempered by my fear that we will inadvertently isolate our scholarship and overly narrow our focus. This would be to the detriment of stateless individuals themselves, who might benefit from the social and policy change our work could help bring about.

As I watch the study of statelessness become increasingly centred in law schools (and to a lesser extent, political science programs), I am reminded of the importance of interdisciplinarity for understanding social issues and rights abuses. Human rights scholars have been resisting disciplinary limitations for years, emphasising the need for research and teaching collaboration across academic fields. This is certainly true in my own work, which is heavily influenced by diverse perspectives in the fields of political science/international relations, anthropology, history, philosophy and sociology, among others. Indeed, I draw from varying perspectives to argue that hierarchies of personhood - inequalities that render some people more 'worthy' than others for protections and political membership - have been created and perpetuated around the world. ${ }^{8}$ This is also true in my approach to human rights education ('HRE') at Webster's Institute for Human Rights and Humanitarian Studies (which I co-founded and currently direct) where faculty fellows from a wide array of academic disciplines teach in the undergraduate program and collaborate on research, advocacy and outreach projects. Indeed, we argue that HRE in higher education has the capacity for positive change within institutions, classrooms and communities. ${ }^{9}$

While statelessness continues to gain attention from scholars and the broader international community, it is noteworthy that existing work has already laid an interdisciplinary foundation for future research and education. For example, we

$5 \quad$ Jack Donnelly and Daniel J Whelan, International Human Rights (Westview, $5^{\text {th }}$ edn, 2018) 26 (emphasis in original).

6 Lindsey N Kingston, 'Worthy of Rights: Statelessness as a Cause and Symptom of Marginalization' in Tendayi Bloom, Katherine Tonkiss and Philip Cole (eds), Understanding Statelessness (Routledge 2017) 17-18.

7 ibid 17.

8 Despite human rights norms to the contrary, some people's rights and dignity are more valued and respected than others; in a sense, some are accepted as more 'fully human' than others. See Lindsey N Kingston, Fully Human: Personhood, Citizenship, and Rights (Oxford University Press 2019).

9 Lindsey N Kingston (ed), Human Rights in Higher Education: Institutional, Classroom, and Community Approaches to Teaching Social Justice (Palgrave Macmillan 2018). 
often start with the 'right to a nationality' guaranteed in the $U D H R$ and within international law (international relations/law). ${ }^{10} \mathrm{We}$ regularly cite Hannah Arendt's 'the right to have rights' 11 and Giorgio Agamben's concept of 'bare life' 12 (political science), and we look back at the Holocaust as a stark example of how statelessness denies people the barest of state protections (history). More recently, a range of social scientists - political theorists, sociologists and anthropologists - increasingly argue that citizenship goes far beyond mere legal status to encompass a broader membership in political community. ${ }^{13}$

Beyond the traditional scope of academia, journalists and artists contribute to our knowledge of statelessness in diverse ways and help the issue emerge within the international community in the process. Documentary photographer Greg Constantine, for instance, is the most recognisable chronicler of statelessness worldwide. His attention to the Rohingya is highlighted in the project Exiled to Nowhere: Burma's Rohingya, ${ }^{14}$ and his work with this stateless population continues in the wake of forced displacement stemming from the 2017 violence. Just as interdisciplinarity strengthens human rights research and education, so too does it benefit our work on the issue of statelessness. While it remains deeply rooted in law and international politics, we cannot fully understand its causes or consequences without engaging from a variety of disciplinary perspectives. We must avoid the pitfall, so common among academic communities, of isolating ourselves in disciplinary bubbles and failing to collaborate with those whose training and perspectives differ from our own.

This is the part where I sheepishly look toward my fellow statelessness researchers and advocates, feeling a bit guilty for raining on the 'statelessness party' we are all so eager to participate in. And not only when it comes to considering it as a new field of study. As my colleagues declare statelessness as 'a concept whose time has come' 15 and argue that 'all signs point to statelessness being an issue that is now here to stay on the international human rights agenda', ${ }^{16}$ I contend that we are still stuck in a situation of 'partial issue emergence' without widespread, non-elite recognition). ${ }^{17}$ My hesitation to embrace a separate field of 'statelessness studies' does not mean that I disregard the incredible advocacy work that went into the creation of new organisations and publications. Nor do I disagree with the assertion that statelessness deserves extensive, sustained scholarship. Rather, I see statelessness as an issue worthy of our attention because of its intricate connection to other political and social concerns. Statelessness is nothing

10 Universal Declaration of Human Rights, GA Res 217A (III), UN GAOR, UN Doc A/810 (10 December 1948) art 15.

11 See generally Hannah Arendt, The Origins of Totalitarianism (Harcourt, Brace \& Co 1951).

12 See generally Giorgio Agamben, Homo Sacer: Sovereign Power and Bare Life (Daniel Heller-Roazen tr, Stanford University Press 1998).

13 See, eg, Kelly Staples, Retheorising Statelessness: A Background Theory of Membership in World Politics (Edinburgh UP 2012); Tendayi Bloom, Katherine Tonkiss and Philip Cole (eds), Understanding Statelessness (Routledge 2017).

14 Greg Constantine, Exiled to Nowhere: Burma's Rohingya (Nowhere People 2012). See also Greg Constantine, 'Nowhere People'<www.nowherepeople.org>.

15 Michelle Foster and Hélène Lambert, 'Statelessness as a Human Rights Issue: A Concept Whose Time Has Come’ (2016) 28(4) International Journal of Refugee Law 564, 584.

16 Laura van Waas, "“Are We There Yet?" The Emergence of Statelessness on the International Human Rights Agenda' (2014) 32 Netherlands Quarterly of Human Rights 342, 346.

17 Lindsey N Kingston, 'Conceptualizing Statelessness as a Human Rights Challenge: Framing, Visual Representation, and (Partial) Issue Emergence' (2019) 11(1) Journal of Human Rights Practice 52. 
new - people have been living outside of legal nationality and beyond the reach of governments since the birth of our state-centric international system - but the meaning and impacts associated with lack of legal nationality are wholly modern. Legal nationality is used as a prerequisite for enjoying fundamental rights: from attending school to going to the doctor, from voting in elections to protesting unfair policies, from working legally to crossing borders. Further, citizenship often marks friend from enemy, 'us' versus 'them', in contentious debates about identity and belonging. It is legal status, but it is also a marker of membership that extends far beyond ID cards. The power of legal nationality explains why denationalisation is increasingly used as a weapon against those deemed threats to the state, ${ }^{18}$ just as citizenship is used as a reward for those seen as extraordinary. ${ }^{19}$

Therefore, my advice in this discussion is not to necessarily abandon the concept of 'statelessness studies', but rather to undertake this scholarship and advocacy with full recognition that statelessness is complicated. It cannot be neatly categorized within any academic discipline or assigned any one-size-fits all 'solution.' In order to move this conversation forward, we must resist the urge to narrow our focus and constrict our scholarly explorations. Indeed, the growing support and enthusiasm for studying statelessness means that we finally have the political and academic space to dig deeper and engage with this issue in important, impactful and diverse ways. This, my friends and colleagues, is where things get interesting.

18 See, eg, Nisha Kapoor, Deport, Deprive, Extradite: $21^{\text {st }}$ Century State Extremism (Verso 2018).

19 French President Emmanuel Macron promised Malian migrant Mamoudou Gassama citizenship in 2018, for instance, in recognition of his extraordinary heroics. Nicknamed 'Spider Man,' Gassama climbed four stories to save a child dangling from the balcony of a Paris flat. Kim Willsher, "Spider-Man" of Paris to Get French citizenship after child rescue' The Guardian (29 May 2018) <https://www.theguardian.com/world/2018/may/28/spiderman-of-paris-to-get-french-citizenship-after-rescuing-child>. 